\title{
Impact of Front Line Demonstration on Yield and Economics of Chickpea (Cicer arietinum) in Uttar-Bastar Kanker District of Chhattisgarh
}

\author{
Chandu Lal Thakur ${ }^{1 *}$, Birbal Sahu ${ }^{1}$, Suresh Kumar Markam² \\ and Upendra Kumar $\mathrm{Nag}^{3}$ \\ ${ }^{1}$ Department of Agronomy, ${ }^{2}$ Department of Horticulture, ${ }^{3}$ Department of Plant Pathology, \\ Krishi Vigyan Kendra, Kanker, Chhattisgarh, India \\ *Corresponding author
}

\section{A B S T R A C T}

\section{Keywords}

Chickpea,

Demonstration,

Technology gap

Article Info

Accepted:

17 May 2019

Available Online:

10 June 2019
Chickpea (Cicer arietinum L.) is commonly known as gram which is one of the important pulse crops of the State. Front line demonstrations were conducted at 100 farmer's field in 40 hectares of 11 villages. To demonstrate production potential and economic benefits of improved technologies comprised viz., improve varieties (JAKI 9218 and JG 14) with seed rate of $75 \mathrm{~kg} / \mathrm{ha}$, line sowing with spacing of $30 \mathrm{~cm}(\mathrm{R}-\mathrm{R})$ and $10 \mathrm{~cm}(\mathrm{P}-\mathrm{P})$, seed treatment with bavistin $2 \mathrm{~g} / \mathrm{kg}$ seed, balance dose of fertilizer, weed management and plant protection measures. The demonstrations were carried out in the Uttar-Bastar Kanker district of Chhattisgarh during rabi season of 2015-16 to 2018-19. The improved technologies gave higher yields and recorded mean yield of 10.16 q/ha which was 46 per cent higher than the farmers practice i.e. $6.95 \mathrm{q} / \mathrm{ha}$.

\section{Introduction}

Chickpea (Cicer arietinum L.) is the premier pulse crop grown in 9.5 million ha with annual production of 9.0 million tonnes with an average productivity of $951 \mathrm{~kg} / \mathrm{ha}$ in India (FAO, STAT 2017). Chickpea is mainly grown during rabi season in India under diverse production systems including both rain fed and irrigated. Chickpea is most important pulse crop of India in terms of both area and production. It is a good source of protein, carbohydrate, fat, minerals and vitamins. It is an excellent animal feed. Madhya Pradesh, Uttar Pradesh, Rajasthan,
Maharashtra, Gujarat, Andhra Pradesh, Karnataka and Chhattisgarh are the major chickpea growing states sharing over 95 per cent area. During last five decades, chickpea has registered significant increase in production, which is primarily due to introduction of high yielding and disease resistant varieties and adoption of improved production technologies. Even though, pulses production increased significantly during the last decade but continuing the faster growth is a bigger challenge for researchers, extension agencies and policy makers to fulfill the domestic demand in India. In the district of Kanker average productivity of chickpea is 
$8.4 \mathrm{q} / \mathrm{ha}$ which is quite low as compared to state productivity. Hence there is need to reduce yield gap, which is possible by farmers adoption of the recommended package of practices (Reddy et al., 2007). Keeping this in view, front line demonstrations of chickpea were conducted, to demonstrate the production potential of latest improved technologies among tribal farmers of UttarBastar Kanker District of Chhattisgarh.

\section{Materials and Methods}

Front line demonstration (FLDs) on chickpea was conducted by Krishi Vigyan Kendra, Kanker (Chhattisgarh), India during the period from 2015-16 to 2018-19 in 11 villages viz., Kapasi, Sureli, Puswada, Albeda, Mode, Turakhar, Choriya, Telawat, Dhanelikanhar, Vyashkongera and Aturgoan of Uttar-Bastar Kanker district. Total 100 demonstrations were conducted. In general soil of the area under study was sandy loam with low to medium fertility status. The component demonstration of front line technology in chickpea was comprised i.e. improved variety JAKI 9218, JG 14, proper tillage, proper seed rate and sowing method, balance dose of

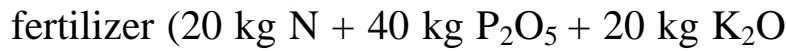
/ha), use of bavistin @ $2 \mathrm{~g} / \mathrm{kg}$ of seed as seed treatment with Rhizobium and PSB culture inoculation @ $10 \mathrm{gm} / \mathrm{kg}$ of seed, proper irrigation, weed management and plant protection measure (Table 1).

Total 40 ha area was covered in four consecutive years. In the demonstration, one control plot was also kept where farmers practices was carried out. The FLD was conducted to study the technology gap between potential yield and demonstrated yield, extension gap between demonstrated yield and yield under existing practice and technology index. The yield data were collected from both the demonstration and farmers practice by random crop cutting method and analyzed by using simple statistical tools. The technology gap, extension gap and technological index (Samui et al., 2000) were calculated by using following formula as given below:

Demonstration yield - Farmer practice yield Per cent increase yield = --------------- $\mathrm{x} 100$

Farmer practice yield

Technology gap $=$ Potential yield Demonstration yield.

Extension gap $=$ Demonstration yield Farmer practice yield.

Potential yield - Demonstration yield Technology index = ------------------ x 100 Potential yield

\section{Results and Discussion}

The gap between the existing and recommended technologies of chickpea in Uttar-Bastar Kanker district was presented in table 1. Full gap was observed in case of HYVs, seed treatment, seed inoculation, fertilizer dose and weed management whereas, partial gap was observed in spacing, irrigation and plant protection measure, which definitely was the reason of not achieving potential yield. Farmers were not aware about recommended technologies. In general, farmers used local or age old varieties instead of the recommended high yielding resistant varieties. Unavailability of seed in time and lack of awareness were the main reasons.

Using four years of FLD results obtained are presented in table 2 . The data revealed that the average yield was recorded $10.16 \mathrm{q} / \mathrm{ha}$ in the demonstrated field which was 46 per cent higher than the farmers practice $6.95 \mathrm{q} / \mathrm{ha}$. The highest yield $10.29 \mathrm{q} / \mathrm{ha}$ was found in demonstrated plot during 2016-17 and 7.25 $\mathrm{q} / \mathrm{ha}$ under farmers practice in 2018-19. 
Table.1 Differences between improved practice and farmers practices under front line demonstration on chickpea

\begin{tabular}{|c|c|c|c|c|}
\hline S. No. & Component & Improved practice & Farmers practice & Gap \\
\hline 1 & Land preparation & Three ploughing & Three ploughing & Nil \\
\hline 2 & Variety & $\begin{array}{l}\text { Improved variety (JAKI 92-18 and JG } \\
\text { 14) }\end{array}$ & Age old variety & Full \\
\hline 3 & Seed rate & $75 \mathrm{~kg} / \mathrm{ha}$ & $100-120 \mathrm{~kg} / \mathrm{ha}$ & Higher seed rate \\
\hline 4 & Seed treatment & Bavistin@3 g/kg of seed & No seed treatment & Full \\
\hline 5 & Seed inoculation & $\begin{array}{l}\text { Rhizobium and PSB culture @ } 10 \mathrm{~g} / \mathrm{kg} \\
\text { of seed }\end{array}$ & No seed inoculation & Full \\
\hline 6 & Sowing method & Line sowing & Broadcasting & Full \\
\hline 7 & Plant population & Optimum & Uneven & Full \\
\hline 8 & Fertilizer dose & $\begin{array}{l}20 \mathrm{~kg} \mathrm{~N}+40 \mathrm{~kg} \mathrm{P}_{2} \mathrm{O}_{5}+20 \mathrm{~kg} \mathrm{~K}_{2} \mathrm{O} / \\
\text { ha }\end{array}$ & $\begin{array}{l}\text { Imbalance and } \\
\text { inadequate }\end{array}$ & Full \\
\hline 9 & Weed management & $\begin{array}{l}\text { Pendamethalin @ } 1 \mathrm{~kg} \text { a.i./ha + One } \\
\text { hand weeding }\end{array}$ & Weeding is not common & Full \\
\hline 10 & $\begin{array}{l}\text { Irrigation at Critical } \\
\text { stage }\end{array}$ & $\begin{array}{l}\text { Two irrigations at pre flowering and } \\
\text { pod development stage }\end{array}$ & Two irrigations & Partial \\
\hline 11 & Plant protection & $\begin{array}{l}\text { Application of recommended } \\
\text { dose of insecticide at proper time }\end{array}$ & $\begin{array}{l}\text { - Use of incorrect } \\
\text { dose } \\
\text { is not common }\end{array}$ & Partial \\
\hline
\end{tabular}

Table.2 Productivity, extension gap, technology gap and technology index of chickpea as grown under FLD and existing package of practices

\begin{tabular}{|c|c|c|c|c|c|c|c|c|c|c|}
\hline \multirow[t]{2}{*}{ Year } & \multirow{2}{*}{$\begin{array}{c}\text { Area } \\
\text { (ha) }\end{array}$} & \multirow{2}{*}{$\begin{array}{c}\text { No. of } \\
\text { Demonstration }\end{array}$} & \multirow[t]{2}{*}{ Variety } & \multicolumn{3}{|c|}{ Average yield (q/ha) } & \multirow{2}{*}{$\begin{array}{c}\% \\
\text { increase in } \\
\text { yield over } \\
\text { farmer } \\
\text { practice }\end{array}$} & \multirow{2}{*}{$\begin{array}{c}\text { Extensio } \\
\text { n gap } \\
\text { (q/ha) }\end{array}$} & \multirow{2}{*}{$\begin{array}{c}\text { Technology } \\
\text { gap (q/ha) }\end{array}$} & \multirow{2}{*}{$\begin{array}{l}\text { Technology } \\
\text { Index }\end{array}$} \\
\hline & & & & Potential & Demonstration & $\begin{array}{l}\text { Farmers } \\
\text { practice }\end{array}$ & & & & \\
\hline $\begin{array}{l}2015- \\
16\end{array}$ & 10 & 10 & $\begin{array}{c}\text { JAKI 92- } \\
18 \& \text { JG } \\
14\end{array}$ & 15 & 10.20 & 6.75 & 51 & 3.45 & 4.80 & 32.00 \\
\hline $\begin{array}{l}2016- \\
17\end{array}$ & 10 & 10 & $\begin{array}{c}\text { JAKI 92- } \\
18 \& \text { JG } \\
14\end{array}$ & 15 & 10.29 & 6.95 & 48 & 3.34 & 4.71 & 31.40 \\
\hline $\begin{array}{l}2017- \\
18\end{array}$ & 10 & 10 & $\begin{array}{c}\text { JAKI 92- } \\
18 \& \text { JG } \\
14\end{array}$ & 15 & 9.98 & 6.83 & 46 & 3.15 & 5.02 & 33.47 \\
\hline $\begin{array}{l}2018- \\
19\end{array}$ & 10 & 10 & $\begin{array}{c}\text { JAKI 92- } \\
18 \& \text { JG } \\
14\end{array}$ & 15 & 10.18 & 7.25 & 40 & 2.93 & 4.82 & 32.13 \\
\hline \multicolumn{5}{|c|}{ Average } & 10.16 & 6.95 & 46 & 3.22 & 4.84 & 32.25 \\
\hline
\end{tabular}


Table.3 Economics of chickpea through front line demonstration

\begin{tabular}{|c|c|c|c|c|c|c|c|c|}
\hline \multirow{2}{*}{ Year } & \multicolumn{2}{|c|}{$\begin{array}{c}\text { Average cost of cultivation } \\
\text { (Rs/ha) }\end{array}$} & \multicolumn{2}{c|}{$\begin{array}{c}\text { Average gross return } \\
\text { (Rs/ha) }\end{array}$} & \multicolumn{2}{c|}{$\begin{array}{c}\text { Average net return } \\
\text { (Rs/ha) }\end{array}$} & \multicolumn{2}{c|}{ Benefit cost ratio } \\
\cline { 2 - 10 } & Demonstration & $\begin{array}{c}\text { Farmers } \\
\text { practice }\end{array}$ & Demonstration & $\begin{array}{c}\text { Farmers } \\
\text { practice }\end{array}$ & Demonstration & $\begin{array}{c}\text { Farmers } \\
\text { practice }\end{array}$ & Demonstration & $\begin{array}{c}\text { Farmers } \\
\text { practice }\end{array}$ \\
\hline $\mathbf{2 0 1 5 - 1 6}$ & 15800 & 14800 & 39292 & 24700 & 23492 & 9900 & 2.49 & 1.67 \\
\hline $\mathbf{2 0 1 6 - 1 7}$ & 20600 & 18900 & 50150 & 29500 & 30840 & 10700 & 2.50 & 1.57 \\
\hline $\mathbf{2 0 1 7 - 1 8}$ & 20800 & 18800 & 49900 & 29000 & 29100 & 10200 & 2.40 & 1.54 \\
\hline $\mathbf{2 0 1 8 - 1 9}$ & 21700 & 19500 & 51440 & 32500 & 31050 & 13600 & 2.63 & 1.72 \\
\hline Average & $\mathbf{1 9 0 7 5}$ & $\mathbf{1 7 8 2 5}$ & $\mathbf{4 7 6 9 6}$ & $\mathbf{2 8 9 2 5}$ & $\mathbf{2 8 6 2 1}$ & $\mathbf{1 1 1 0 0}$ & $\mathbf{2 . 5 0}$ & $\mathbf{1 . 6 3}$ \\
\hline
\end{tabular}

*Selling price of chickpea was 3800, 5000, 4500 and 4200 Rs./q in 2015-16, 2016-17, 2017-18 and 2018-19 respectively.

This results clearly indicated that the higher average grain yield in demonstration plots over the years compare to farmers practice due to knowledge and adoption of full package of practices i.e. suitable varieties such as JAKI 9218, JG 14 etc, timely sowing, seed treatment, use of balance dose of fertilizer, timely weed management and need based plant protection.

The yield of chickpea could be increased over the yield obtained under farmers practice (use of old variety, untimely sowing, no use of balanced dose of fertilizer, no plant protection measure) of chickpea cultivation. The above findings are in similarly with the findings of Singh (2002).

The technology gap were 4.80, 4.71, 5.02 and $4.84 \mathrm{q} / \mathrm{ha}$ during 2015-16, 2016-17, 2017-18 and 2018-19, respectively. On an average technology gap in the four years FLD programme was $4.84 \mathrm{q} / \mathrm{ha}$. The technology gap observed may be attributed to dissimilarity in the soil fertility status, agricultural practices and local climatic situation. The Extension gap of 3.45, 3.34, 3.15 and $2.93 \mathrm{q} / \mathrm{ha}$ were observed during 2015-16, 2016-17, 2017-18 and 2018-19, respectively. On an average extension gap was observed $4.84 \mathrm{q} / \mathrm{ha}$, which emphasized the need to educate the farmers through various extension means. The technology index varied from 31.40 to 33.47 per cent (Table 2). On an average technology index was observed 32.25 per cent, which shows the efficacy of good performance of technical interventions. This will accelerate the yield performance of chickpea (Mishra and Khare 2017).

The economic viability of improved technologies over farmer' practices were calculated depending on prevailing prices of inputs and outputs costs (Table 3). It was found that cost of cultivation of chickpea varied from Rs. 15800 to Rs. 21700/ha with an average of Rs. 19075/ha of demonstration as against the variation in cost of cultivation from Rs. 14800 to Rs. 19500/ha with an average of Rs. 17825/ha in farmers practice.

Cultivation of chickpea in the demonstration gave higher net return ranged from Rs. 23492 to Rs. 31050/ha with a mean value of Rs. 28621/ha as compared to farmers practice which recorded Rs. 9900 to Rs. 13600/ha with a mean of Rs. 11100/ha. The higher benefit cost ratio $2.49,2.50,2.40$ and 2.63 were found under demonstration compared to 1.67 , $1.72,1.54$ and 1.57 under farmers practice in the corresponding seasons. This may be due to higher yields obtained under demonstrations compared to farmers practice. 


\section{References}

FAO, STAT (2017). Food and agriculture organization STAT- Statistical Database, 2017.

Mishra, P. K. and Khare, Y. R. 2017. Impact of front line demonstration on yield and profitability of chickpea (Cicer Arietinum) in Sagar district of Bundelkhand region of Madhyapradesh, India. Plant Archives, 17 (1): 463-466.

Reddy, A. A., V. C. Mature, M. Yadav and S. S. Yadav (2007). Profitablity in chickpea cultivation. Pages 292-321. In: The Chickpea Breeding and
Management (Yadav, S. S., B. Redden, W. Chen and B. Sharma eds). Wallingford, Oxon. UK: CAB International.

Samui, S. K., S. Maitra, D. K. Roy, A. K. Mondal and D. Saha (2000). Evaluation on front line demonstration on groundnut (Arachis hypogea L.). Journal of Indian Society of Coastal Agriculture Research, 18: 180-183.

Singh, P. K. (2002). Impact of participation in planning on adoption of new technology through FLD. MANAGE Extension Research Review, July-Dec. 45-48.

\section{How to cite this article:}

Chandu Lal Thakur, Birbal Sahu, Suresh Kumar Markam and Upendra Kumar Nag. 2019. Impact of Front Line Demonstration on Yield and Economics of Chickpea (Cicer arietinum) in Uttar-Bastar Kanker District of Chhattisgarh. Int.J.Curr.Microbiol.App.Sci. 8(06): 2337-2341. doi: https://doi.org/10.20546/ijcmas.2019.806.277 